\title{
Effect of metabolic control on parathyroid hormone secretion in diabetic patients
}

F.J.A. Paula, C.M.M. Lanna,

T. Shuhama and M.C. Foss
Departamento de Clínica M édica, Faculdade de Medicina de Ribeirão Preto, Universidade de São Paulo, Ribeirão Preto, SP, Brasil

\section{Correspondence \\ M.C. Foss \\ Departamento de Clínica Médica \\ FMRP, USP \\ Av. Bandeirantes, 3900 \\ 14049-900 Ribeirão Preto, SP \\ Brasil \\ E-mail: mcfoss@fmrp.usp.br}

Research supported by FAPESP, CNPq and FAEPA.

Received August 30, 2000

Accepted July 6, 2001

\section{Abstract}

The metabolic derangement caused by diabetes mellitus may potentially affect bone mineral metabolism. In the present study we evaluated the effect of diabetes metabolic control on parathyroid hormone (PTH) secretion during stimulation with EDTA infusion. The study was conducted on 24 individuals, 8 of them normal subjects (group N: glycated hemoglobin $-\mathrm{HbA}_{1 \mathrm{C}}=4.2 \pm 0.2 \%$; range $\left.=3.5-5.0 \%\right), 8$ patients with good and regular metabolic control (group G-R: $\mathrm{HbA}_{1 \mathrm{C}}$ $=7.3 \pm 0.4 \%$; range $=6.0-8.5 \%$ ), and 8 patients with poor metabolic control (group P: $\mathrm{HbA}_{1 \mathrm{C}}=12.5 \pm 1.0 \%$; range: $10.0-18.8 \%$ ). Blood samples were collected at 10-min intervals throughout the study (a basal period of $30 \mathrm{~min}$ and a $2-\mathrm{h}$ period of EDTA infusion, $30 \mathrm{mg} / \mathrm{kg}$ body weight) and used for the determination of ionized calcium, magnesium, glucose and intact PTH. Basal ionized calcium levels were slightly lower in group $\mathrm{P}(1.19 \pm 0.01 \mathrm{mmol} / \mathrm{l})$ than in group $\mathrm{N}$ $(1.21 \pm 0.01 \mathrm{mmol} / \mathrm{l})$ and group G-R $(1.22 \pm 0.01 \mathrm{mmol} / \mathrm{l})$. After EDTA infusion, the three groups presented a significant fall in calcium, but with no significant difference among them at any time. Basal magnesium levels and levels determined during EDTA infusion were significantly lower $(\mathrm{P}<0.01)$ in group $\mathrm{P}$ than in group $\mathrm{N}$. The induction of hypocalcemia caused an elevation in PTH which was similar in groups $\mathrm{N}$ and $\mathrm{G}-\mathrm{R}$ but significantly higher than in group $\mathrm{P}$ throughout the infusion period $(+110 \mathrm{~min}, \mathrm{~N}=11.9 \pm 2.1 v s \mathrm{G}-\mathrm{R}=13.7 \pm 1.6 v \mathrm{~s}$ $\mathrm{P}=7.5 \pm 0.7 \mathrm{pmol} / \mathrm{l} ; \mathrm{P}<0.05$ for $\mathrm{P}$ vs $\mathrm{N}$ and $\mathrm{G}-\mathrm{R})$. The present results show that PTH secretion is impaired in patients with poorly controlled diabetes.

\section{Introduction}

Poor metabolic control of diabetes mellitus can induce alterations in calcium homeostasis (1). As a consequence, an increase in parathyroid hormone (PTH) secretion may occur to correct for any possibility of a reduction in calcium. However, the complete disturbance of mineral metabolism observed in diabetes mellitus also involves alterations

\section{Key words}

- Diabetes mellitus complications

- Mineral metabolism

- Parathormone secretion ....................... 
humerus and foot fractures among older women $(2,3)$.

Seino and Ishida (1) reviewed several points concerning osteopenia and diabetes mellitus: a) urinary waste of calcium, phosphorus and magnesium is correlated with the intensity of glycosuria (4-6) and McNair et al. (6) have shown that serum calcium and PTH are slightly lower in diabetics than in controls; b) with respect to alterations in vitamin D metabolism, Frazer et al. (7) reported that $1,25(\mathrm{OH})_{2} \mathrm{D}$ levels are lower in patients with IDDM, whereas other studies have pointed out an increase in $1,25(\mathrm{OH})_{2} \mathrm{D}$ clearance (8), and still others have suggested a reduction in the number of receptors for this hormone (9), and c) another line of investigation has related insulin deficiency to reduction in osteoblast activity as demonstrated by a reduction in serum osteocalcin levels in diabetic rats (10).

Since the classical Diabetes Control and Complications Trial in 1993 (11), and more recently the United Kingdom Prospective Diabetes Study (12), a factor to be always considered in the evaluation of diabetic complications is metabolic control and, more particularly, the hyperglycemic state. Thus, the major objective of the present study was to evaluate PTH secretion in diabetic patients with different degrees of metabolic control, in view of the fact that a) PTH is a physiologically important hormone for the

Table 1. Clinical characteristics of normal subjects (group N), and diabetic subjects with good or regular (group G-R) or poor (group P) metabolic control.

\begin{tabular}{lccccc}
\hline Group & Age (years) & Weight $(\mathrm{kg})$ & Height $(\mathrm{cm})$ & $\mathrm{BMI}\left(\mathrm{kg} / \mathrm{m}^{2}\right)$ & $\mathrm{HbA}_{1 \mathrm{c}}(\%)$ \\
\hline $\mathrm{N}$ & $28.4 \pm 1.9$ & $67.8 \pm 4.9$ & $171.2 \pm 4.1$ & 22.9 & 4.2 \\
& $24.0-36.0$ & $49.3-82.8$ & $152.0-181.5$ & $20.5-25.3$ & $3.5-5.0$ \\
$\mathrm{G}-\mathrm{R}$ & $29.9 \pm 2.3$ & $64.4 \pm 2.5$ & 164.1 & 23.8 & 7.3 \\
& $19.0-40.0$ & $53.0-72.5$ & $147.0-171.5$ & $20.8-26.3$ & $6.0-8.5$ \\
$\mathrm{P}$ & $27.4 \pm 2.3$ & $69.0 \pm 2.7$ & 166.1 & 24.3 & 12.5 \\
& $19.0-36.0$ & $62.0-79.5$ & $153.5-186.0$ & $19.1-30.3$ & $10.0-18.8$ \\
\hline
\end{tabular}

The results are reported as means \pm SEM and ranges. $\mathrm{BMI}=$ body mass index; $\mathrm{HbA}_{1 \mathrm{c}}$ = glycated hemoglobin. maintenance of bone trophism (13), b) when secreted in excessive amounts its predominant effect is osteolysis (14), and c) PTH is one of the major stimuli for $1,25(\mathrm{OH})_{2} \mathrm{D}$ synthesis (15) and osteoblast activity (16). The model used was induction of hypocalcemia by EDTA infusion.

\section{Material and Methods}

The study was conducted on 24 individuals, 8 of them normal (group N, 5 males and 3 females), 8 with diabetes mellitus under good or regular metabolic control (group G-R, 4 males and 4 females), and 8 with diabetes mellitus under poor metabolic control (group P, 4 males and 4 females). The three groups did not differ significantly in terms of age, body weight, height, or body mass index (Table 1).

The study was approved by the Ethics Committee of the University Hospital, Faculty of Medicine of Ribeirão Preto, USP, and all subjects gave informed consent to participate.

The three groups were defined on the basis of clinical history and fasting plasma glucose and glycated hemoglobin $\left(\mathrm{HbA}_{\mathrm{lc}}\right) \mathrm{de}$ termination. The normal individuals had no personal or family history of diabetes mellitus and presented fasting glycemia levels ranging from 3.9 to $5.3 \mathrm{mmol} / \mathrm{l}$ and $\mathrm{HbA}_{\mathrm{lc}}$ ranging from 3.5 to $5.0 \%$. The G-R group consisted of six patients with diabetes mellitus type 1 and two patients with diabetes mellitus type 2, with fasting glycemia levels ranging from 3.9 to $9.0 \mathrm{mmol} / \mathrm{l}$ and $\mathrm{HbA}_{\mathrm{lc}}$ ranging from 6.0 to $8.5 \%$. Diabetic patients with poor metabolic control presented $\mathrm{HbA}_{1 \mathrm{c}}$ of 10 to $18.8 \%$ and fasting glycemia of 12.2 to $19.6 \mathrm{mmol} / \mathrm{l}$. In this group, six individuals had diabetes mellitus type 1 and two diabetes mellitus type 2. Subjects with a history of tabacco smoking, alcoholism, use of drugs with known effects on mineral metabolism (estrogen, barbiturics, vitamin D, diuretics, corticosteroids, and thyroid hormones) and 
diabetic nephropathy (microalbuminuria, creatinine and ureic nitrogen) were excluded from the study.

The experiments were conducted with the patients in the supine position in a metabolic study room at a constant temperature of $22^{\circ} \mathrm{C}$. Cubital veins were cannulated in each forearm with 20 -gauge butterfly catheters for blood collections and solution infusion, respectively. Blood samples were collected at 10-min intervals during the basal period (30 min) and during a 2-h period of EDTA infusion. The infusion solution was prepared immediately before administration and contained $30 \mathrm{mg} / \mathrm{kg}$ weight EDTA, 2.7 $\mathrm{mg} / \mathrm{kg}$ weight xylocaine, and $5 \%$ glucose for a total volume of $200 \mathrm{ml}$. The solution was infused with an infusion pump (Harvard apparatus) into the contralateral arm to that used for blood collection. The blood samples were used for the determination of plasma glucose by a glucose oxidase technique using a Beckman glucose analyzer II (Beckman Instruments, Fullerton, CA, USA) and glycated hemoglobin was determined by an affinity chromatography method (17). Ionized calcium was measured in blood obtained with a 3-ml syringe containing calcium-titrated heparin $\left(2560^{\mathrm{TM}}\right.$ Radiometer, Copenhagen, Denmark) using an analyzer with a calcium-specific electrode (Radiometer ICA II) (18). The samples were collected anaerobically and the measurements were made immediately after collection. Blood samples for the determination of intact PTH were centrifuged in a refrigerated centrifuge and frozen at $-70^{\circ} \mathrm{C}$ until the day for determination. Serum PTH was analyzed in duplicate by an immunoradiometric method (Nichols Diagnostic Institutes, San Juan Capistrano, CA, USA). The intra- and interassay coefficients of variation were 4.9 and $11.0 \%$, respectively. Serum magnesium was determined in duplicate by atom absorption spectrophotometry using a Perkin-Elmer apparatus (Perkin Elmer, Norwalk, CT, USA).
Data are reported as means \pm SEM and were analyzed using the Graphpad Prism 1999 software (Graphpad Software Inc., San Diego, CA, USA). The Friedman test, twoway analysis of variance by ranks, was used for paired parameters and the Kruskal-Wallis test was used for unpaired variables. Dunn's post test was used in both analyses. The level of significance was set at $\mathrm{P}<0.05$.

\section{Results}

The normal group presented a significantly lower fasting glycemia than group G$\mathrm{R}(\mathrm{N}=4.4 \pm 0.1 \mathrm{mmol} / \mathrm{l} v s \mathrm{G}-\mathrm{R}=6.1 \pm 0.6$ $\mathrm{mmol} / \mathrm{l}, \mathrm{P}<0.05)$ and group $\mathrm{P}(\mathrm{P}=13.6 \pm 1.7$ $\mathrm{mmol} / \mathrm{l}, \mathrm{P}<0.005)$. The difference in glycemia levels between the two groups of diabetic individuals was significant $(\mathrm{P}<0.01)$.

After the beginning of EDTA infusion, the normal group presented a slight variation in plasma glucose, with the highest values being reached at $120 \mathrm{~min}(4.7 \pm 0.04 \mathrm{mmol} / \mathrm{l})$. The diabetic groups also showed a small variation in glycemia during EDTA infusion, with the peak occurring at $120 \mathrm{~min}$ in the G-R group $(7.9 \pm 0.8 \mathrm{mmol} / \mathrm{l})$ and at 80 $\mathrm{min}$ in the $\mathrm{P}$ group $(14.1 \pm 1.9 \mathrm{mmol} / \mathrm{l})$. The plasma glucose levels of the $\mathrm{P}$ group were significantly higher than those for the G-R group $(\mathrm{P}<0.005)$ throughout the period of infusion and the latter group presented significantly higher plasma glucose levels than the $\mathrm{N}$ group throughout the study $(\mathrm{P}<0.05)$ (Figure 1A).

The $\mathrm{P}$ group tended to present lower calcium ion levels than the other two groups throughout the study. After the beginning of EDTA infusion, the three groups presented a significant reduction in circulating calcium ion levels corresponding to $18.6 \%$ (from $1.21 \pm 0.01$ to $1.02 \pm 0.02 \mathrm{mmol} / \mathrm{l}$ ) for group $\mathrm{N}, 18.4 \%$ (from $1.22 \pm 0.01$ to $1.03 \pm 0.01$ $\mathrm{mmol} / \mathrm{l}$ ) for group $\mathrm{G}-\mathrm{R}$, and $12.3 \%$ (from $1.19 \pm 0.01$ to $1.06 \pm 0.01 \mathrm{mmol} / \mathrm{l})$ for group $\mathrm{P}$, respectively (Figure 1B).

In the basal state, circulating PTH levels 
were similar for groups $\mathrm{N}$ and G-R, while group $\mathrm{P}$ showed a slight tendency to lower serum PTH levels $(\mathrm{N}=2.5 \pm 0.6$ vs $\mathrm{G}-\mathrm{R}=2.7$ \pm 0.5 vs $\mathrm{P}=2.2 \pm 0.3 \mathrm{pmol} / \mathrm{l})$. This behavior became more marked during the stimulation tests, i.e., after the induction of hypocalcemia serum PTH levels became significantly lower in $\mathrm{P}$ patients $(\mathrm{P}<0.05)$, whereas no difference in PTH levels was observed between $\mathrm{N}$ and $\mathrm{G}-\mathrm{R}$ patients. The maximum

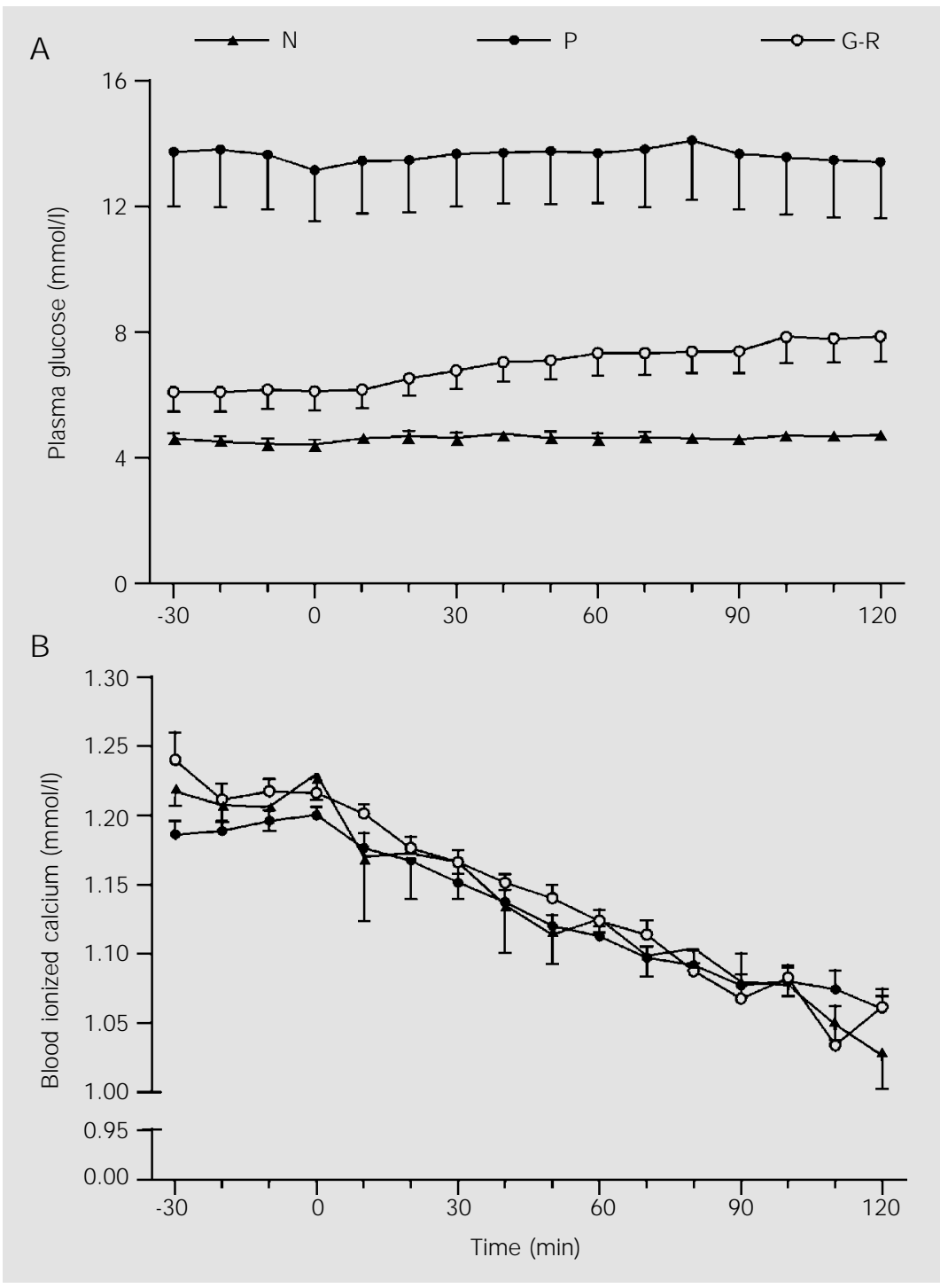

Figure 1. Plasma glucose (A) and blood ionized calcium (B) determined under basal conditions (-30 to $0 \mathrm{~min}$ ) and during $2 \mathrm{~h}$ of EDTA infusion in normal subjects (group $\mathrm{N}$ ), diabetic patients with good or regular metabolic control (group G-R), and in diabetic patients with poor metabolic control (group P). A, $\mathrm{P}<0.005$ group N vs group $\mathrm{P}$. $\mathrm{P}<0.05$ group $\mathrm{N}$ vs group G-R. P $<0.01$ group G-R vs group P (Kruskal-Wallis test).
PTH levels during the test were $\mathrm{N}=11.9 \pm$ 2.1 vs $\mathrm{G}-\mathrm{R}=13.7 \pm 1.6$ vs $\mathrm{P}=7.5 \pm 0.7 \mathrm{pmol} /$ 1 (Figure 2A).

Figure 2B shows that serum magnesium levels remained stable throughout the study in the three groups, ranging from $0.73 \pm 0.03$ to $0.76 \pm 0.02 \mathrm{mmol} / \mathrm{l}$ in group $\mathrm{N}$, from 0.69 \pm 0.02 to $0.71 \pm 0.03 \mathrm{mmol} / \mathrm{l}$ in group $\mathrm{G}-\mathrm{R}$, and from $0.64 \pm 0.03$ to $0.66 \pm 0.02 \mathrm{mmol} / \mathrm{l}$ in group P. Magnesium levels were significantly lower in the $\mathrm{P}$ group than in the $\mathrm{N}$ group.

\section{Discussion}

It is well known that alterations in mineral metabolism can induce disturbance in glucose metabolism (19-21) and glucose intolerance which also can interfere with mineral metabolism (22). Previous studies have shown that poor diabetes mellitus control is associated with calcium, phosphorus and magnesium wastage $(4,5)$. We evaluated PTH secretion in diabetic patients with different degrees of metabolic control and our results showed that patients with poor metabolic control present lower PTH secretion than well-controlled diabetic and normal subjects during acute stimulation.

Hyperglycemia that leads to osmotic diuresis also causes magnesium depletion. It is possible that the reduced PTH secretion occurring in patients with poorly controlled diabetes is related to low serum magnesium (23). Magnesium interacts in a complex manner with PTH, interfering both with the secretion and action of this hormone. Acute hypomagnesemia stimulates PTH secretion, whereas chronic severe hypomagnesemia has a negative effect and is the exclusive cause of clinical hypoparathyroidism. Furthermore, hypomagnesemia is associated with a decreased action of PTH on target tissues, possibly by causing a functional impairment of the adenyl cyclase system (24). Magnesium is a predominantly intracellular ion and a normal serum magnesium level does not 
mean a normal content of body magnesium. Lima et al. (22) verified that only intracellular magnesium levels correlate with metabolic control in diabetes mellitus. However, several studies have measured only circulatory levels of magnesium as evidence of hypomagnesemia. Rude et al. (23) have shown that patients with low serum magnesium presented undetectable basal PTH only when magnesium was below $0.35 \mathrm{mmol} / \mathrm{l}$ and that basal PTH was increased or normal in patients with 0.44 and $0.49 \mathrm{mmol} / \mathrm{l}$ serum magnesium levels, respectively. Our results are in accordance with those reported by Rude et al. (23), i.e., normal basal PTH levels in subjects with magnesium higher than $0.44 \mathrm{mmol} / \mathrm{l}$. Furthermore, we observed that the parathyroid response to acute hypocalcemia is impaired in diabetic patients with serum magnesium levels of $0.64 \pm 0.03$ $\mathrm{mmol} / \mathrm{l}$.

Calcium sensors in the parathyroid gland are especially sensitive to serum calcium variations and permit PTH to exert efficiently its most important function, i.e., to maintain calcium homeostasis (25). Another important physiological role of PTH is its participation in the control of bone trophism (13). Whereas exaggerated and constant PTH secretion has a predominantly catabolic effect on bone, its periodic secretion is associated with the maintenance and even an increase in trabecular bone mass in humans $(14,26)$ and with an increase in trabecular and cortical bone in rats (27). The action of PTH favoring the maintenance and/or increase in bone mass may be secondary to its metabolic actions of urine calcium retention and/or to increased intestinal calcium absorption secondary to stimulation of $1,25(\mathrm{OH})_{2} \mathrm{D}$ synthesis or may even be due to a direct activation of osteoblasts, in view of the fact that previous studies have shown PTH receptors in these cells (28).

Our results clearly show that PTH secretion is impaired in patients with poorly controlled diabetes mellitus and suggest an as- sociation between this occurrence and the low serum levels of magnesium observed in these patients. Previous studies have suggested that the osteopenia observed in diabetic patients is due to the reduction in $1,25(\mathrm{OH})_{2} \mathrm{D}$ levels $(7)$ and that insulin deficiency could reduce osteoblast activity $(12,13)$. However, other studies have sug-

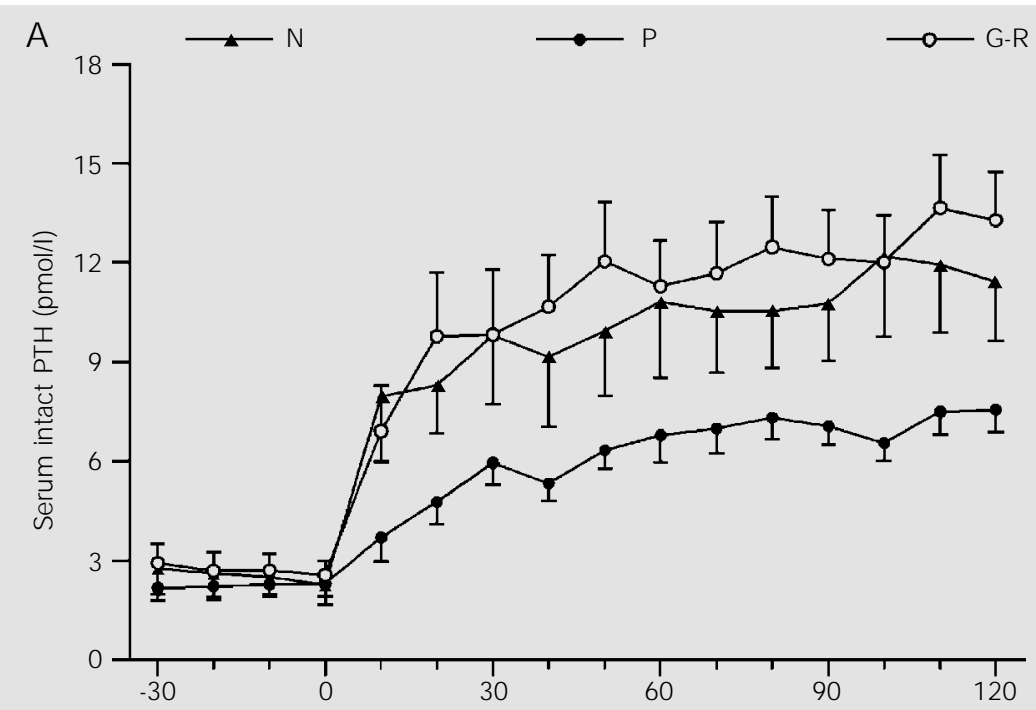

B

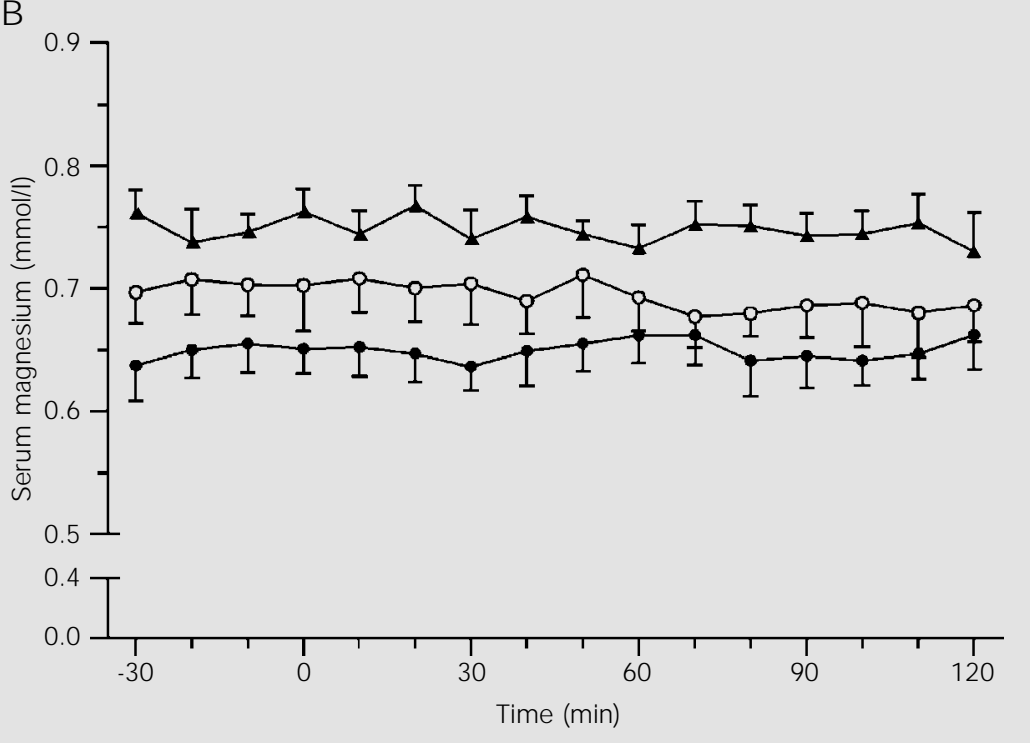

Figure 2. Serum intact PTH (A) and serum magnesium (B) levels under basal conditions (-30 to $0 \mathrm{~min}$ ) and during $2 \mathrm{~h}$ of EDTA infusion in normal subjects (group $\mathrm{N}$ ), in diabetic patients with good or regular metabolic control (group G-R), and in diabetic patients with poor metabolic control (group P). A, $\mathrm{P}<0.05$ group N vs group $\mathrm{P}$ (intervals +60 to $+120 \mathrm{~min}$ ). $P<0.05$ group $G-R$ vs group $P$ (intervals +50 to $+120 \mathrm{~min}$ ). $B, P<0.01$ group $N$ vs group $P$ (Kruskal-Wallis test). 
gested that osteopenia is not a complication of diabetes mellitus (29). Probably, both hypotheses can be considered true in view of the heterogeneous situation of diabetes mellitus. Whereas patients with good metabolic control have normal calcium ion and PTH secretion, poorly controlled diabetics tend to present lower calcium ion levels, deficient PTH secretion and lower serum magnesium levels. Thus, on the basis of these alterations, it is possible that osteopenia is a nonclassical complication of diabetes which is likely to be related to hyperglycemia. It is also possible that decreased PTH secretion contributes to a reduction of $1,25(\mathrm{OH})_{2} \mathrm{D}$ levels and of osteoblast activity in diabetics.

\section{Acknowledgments}

The authors gratefully acknowledge S.L. Brandão Filho for expert technical help, C. Guimarães and E.F. Verceze for secretarial assistance, and E. Greene for revising the English text.

\section{References}

1. Seino Y \& Ishida H (1995). Diabetic osteopenia. Pathophysiology and clinical aspects. Diabetes and Metabolism Reviews, 11: 21-35.

2. Forsen $L$, Meyer $\mathrm{HE}$, Midthjell $K \&$ Edna TH (1999). Diabetes mellitus and the incidence of hip fracture: results from the Nord-Trondelag health survey. Diabetologia, 42: 920-925.

3. Schwartz AV, Sellmeyer DE, Ensrud KE, Cauley J A, Tabor HK, Schreiner PJ , J amal SA, Black DM \& Cummings SR (2001). Older women with diabetes have an increased risk of fracture: a prospective study. J ournal of Clinical Endocrinology and Metabolism, 86: 32-38.

4. Monnier L, Colette C, Aguirre L, Sony C \& Mirouze J (1978). Intestinal and renal handling of calcium in human diabetes mellitus: influence of acute oral glycose loading and diabetic control. European J oumal of Clinical Investigation, 8: 225-231.

5. Paolisso G, Scheen A, D'Onofrio F \& Lefèbvre $P$ (1990). Magnesium and glucose homeostasis. Diabetologia, 33: 511514.

6. McNair P, Madsbad S, Christiansen C, Christensen MS \& Transbal I (1982). Hyponatremia and hyperkalemia in relation to hyperglycemia in insulin treated diabetic out-patients. Clinica Chimica Acta, 120: 243-250.

7. Frazer TE, White $\mathrm{NH}$, Hough $\mathrm{S}$, Santiago JV, McGee BR, Bryle O, Mallon J \& Avioli LV (1981). Alterations in circulating vitamin D metabolites in the young insulindependent diabetic. J ournal of Clinical Endocrinology and Metabolism, 53: 11541159.

8. Verhaeghe J, Suiken AMH, Van Bree R,
Vaniterck E, J ans I, Visser WJ , Thomasset M, Allewaert K \& Bouillon R (1993). Increased clearance of $1,25(\mathrm{OH})_{2} \mathrm{D}_{3}$ and tissue-specific responsiveness to $1,25(\mathrm{OH})_{2} \mathrm{D}_{3}$ in diabetic rats. American J ournal of Physiology, 265: E215-E223.

9. Ishida H, Cunningham NS, Henry HL \& Norman AW (1988). The number of 1,25dihydroxyvitamin $D_{3}$ receptors is decreased in both intestine and kidney of genetically diabetic ob/db mice. Endocrinology, 122: 2436-2443.

10. Ishida H, Seino Y, Takeshita N, Kurose T, Tsuji K, Okamoto Y, Someya Y, Hara K, Akiyama Y, Imura H \& Nozawa M (1992). Effect of pancreas transplantation on decreased levels of circulating bone $\gamma$ carboxyglutamic acid containing protein and osteopenia in rats with streptozotocin-induced diabetes. Acta Endocrinologica, 127: 81-85.

11. Diabetes Control and Complications Trial Research Group (1993). The effect of intensive treatment of diabetes on the development and progression of long term complications in insulin-dependent diabetes mellitus. New England J ournal of Medicine, 329: 977-986.

12. UK Prospective Diabetes Study (UKPDS) Group (1998). Intensive blood-glucose control with sulfonylureas or insulin compared with conventional treatment and risk of complications in patients with type 2 diabetes (UKPDS 33). Lancet, 352: 837853.

13. Rosen CJ \& Donahue LR (1996). Parathyroid hormone and osteoporosis. Current Opinion in Endocrinology and Diabetes, 3 : 532-539.

14. Garton M, Martin J , Stewart A, Krukowski
Z, Matheson N, Robins S, Lowredge N \& Reid $D$ (1995). Changes in bone mass and metabolism after surgery for primary hyperparathyroidism. Clinical Endocrinology, 42: 493-500.

15. Hughs-Dawson B (1994). Regulation of parathyroid hormone by dietary calcium and vitamin D. In: Bilezakian J P, Marcus R \& Levine NA (Editors), The Parathyroid. Basic and Clinical Concepts. 1st edn. Raven Press, New York.

16. Canalis E, Hock J M \& Raisz LG (1994). Anabolic and catabolic effects of parathyroid hormone on bone and interactions with growth factors. In: Bilezakian J P, Marcus R \& Levine NA (Editors), The Parathyroid. Basic and Clinical Concepts. 1st edn. Raven Press, New York.

17. Klenk DC, Hermanson GT, Krohn RI, Fujimoto EJ, Mallia AK, Smith PK, England J D, Wiedmeyer $\mathrm{H}$, Little RR \& Goldstein DE (1982). Determination of glycosylated hemoglobin by affinity chromatography: comparison with colorimetric and ion-exchange method and effects of common interferences. Clinical Chemistry, 28: 2088-2094.

18. Bowers J r GN, Brasard C \& Sena SF (1986). Measurements of ionized calcium in serum with ion-selective electrodes: a mature technology that can meet the daily service needs. Clinical Chemistry, 32: 1437-1447.

19. Paula FJA, Plens AECM \& Foss $M C$ (1998). Effects of hypophosphatemia on glucose tolerance and insulin secretion. Hormone and Metabolic Research, 30: 281-284.

20. Kumar S, Olukoga AO, Gordon C, Mawer EB, France $M$, Hosker IP, Davies M \& 
Bourton AJ M (1994). Impaired glucose tolerance and insulin sensitivity in primary hyperparathyroidism. Clinical Endocrinology, 40: 47-53.

21. Rosolova H, Mayer O \& Reaven G (1997). Effect of variation in plasma magnesium concentration on resistance to insulinmediated glucose disposal in nondiabetic subjects. J ournal of Clinical Endocrinology and Metabolism, 82: 3783-3785.

22. Lima ML, Rodrigues LE, Cruz T, Barbosa K, Pousada CP \& Canguçu V (1998). The effect of magnesium supplementation in increasing doses on the control of type 2 diabetes. Diabetes Care, 21: 682-686.

23. Rude RK, Oldhan SB, Sharp CF \& Singer FR (1978). Parathyroid hormone secretion in magnesium deficiency. J oumal of Clinical Endocrinology and Metabolism, 47: 800-806.

24. Rude RK (1996). Magnesium depletion and hypermagnesemia. In: Favas MJ (Editor), Primer on the Metabolic Bone Diseases and Disorders of Mineral Metabolism. 3rd edn. Lippincot-Raven, Philadelphia.

25. Brown EM \& Pollak Hebert SC (1998). The extracellular calcium-sensing receptor: its role in health and disease. Annual Review of Medicine, 49: 15-29.

26. Hodsman $A B$, Steer $B M$, Fraher $L J \&$ Drost DJ (1991). Bone densitometric and histomorphometric response to sequential human PTH (1-38) and salmon calcito- nin in osteoporotic patients. Bone Mineral, 14: 67-83.

27. Guiness-Hey M \& Hock J M (1984). Increased trabecular bone mass in rats treated with human synthetic parathyroid hormone. Metabolic Bone Disease and Related Research, 5: 177-181.

28. McSheehy PHJ \& Chambers TJ (1986). Osteoblastic cells mediate osteoclastic responsiveness to PTH. Endocrinology, 118: 824-828.

29. Van Daele PLA, Stolk RP, Burger H, Algra $D$, Grobbee DE, Hofman AP, Birkenhager J P \& Huibert AP (1995). Bone density in non-insulin-dependent diabetes mellitus. The Rotterdam Study. Annals of Internal Medicine, 122: 409-414. 